\title{
Towards a Generalized Synthetic Strategy for Variable Sized Enantiopure $M_{4} L_{4}$ Helicates
}

\author{
Stephanie A. Boer ${ }^{1,2} \mathbb{D}$, Winnie Cao ${ }^{1}$, Bianca K. Glascott ${ }^{1}$ and David R. Turner ${ }^{1, *(\mathbb{D}}$ \\ 1 School of Chemistry, Monash University, Clayton, VIC 3800, Australia; boers@ansto.gov.au (S.A.B.); \\ wei.cao2@monash.edu (W.C.); biancaglascott13@gmail.com (B.K.G.) \\ 2 Australian Synchrotron, ANSTO, 800 Blackburn Road, Clayton, VIC 3168, Australia \\ * Correspondence: david.turner@monash.edu; Tel.: +61-3-9905-6293
}

Received: 31 May 2020; Accepted: 19 June 2020; Published: 28 June 2020

\begin{abstract}
The reliable and predictable synthesis of enantiopure coordination cages is an important step towards the realization of discrete cages capable of enantioselective discrimination. We have built upon our initial report of a lantern-type helical cage in attempts to expand the synthesis into a general approach. The use of a longer, flexible diacid ligand results in the anticipated cage $\left[\mathrm{Cu}_{4}(\mathbf{L 1})_{4}(\text { solvent })_{4}\right]$ with a similar helical pitch to that previously observed and a cavity approximately $30 \%$ larger. Using a shorter, more rigid ligand gave rise to a strained, conjoined cage-type complex when using DABCO as an internal bridging ligand, $\left[\left\{\mathrm{Co}_{4}(\mathbf{L} 2)_{4}(\mathrm{DABCO})\left(\mathrm{OH}_{2}\right)_{\times}\right\}_{2}(\mathrm{DABCO})\right]$. The expected paddlewheel motif only forms for one of the $\mathrm{Co}_{2}$ units within each cage, with the other end adopting a "partial paddlewheel" with aqua ligands completing the coordination sphere of the externally facing metal ion. The generic approach of using chiral diacids to construct lantern-type cages is partially borne out, with it being apparent that flexibility in the core group is an essential structural feature.
\end{abstract}

Keywords: metal-organic cage; helicate; metallosupramolecular; chirality

\section{Introduction}

The formation of enclosed cages, capable of guest encapsulation, has been a mainstay of the supramolecular field since the early work on carcerands by Cram [1]. There has been particular attention given to the use of metal ions as structural agents in the formation of coordination cages, with their relatively predictable coordination geometries allowing for a good degree of control over the self-assembling synthesis [2-8]. The use of cages as agents for guest discrimination is prevalent in the literature, with the internal cavities providing excellent size and shape discrimination between analytes. Such discrimination should lend itself well to separations of racemic mixtures and there is growing literature regarding the synthesis of chiral self-assembled cages [9-12].

There have been a number of different approaches towards chiral coordination cages reported in the literature, although far fewer than reports of achiral (or racemic) systems. Tetrahedral metallo-supramolecular cages, with metal ions situated at the corners of the cage, can have tris-chelated octahedral metal centres that, by definition, have either $\Lambda$ or $\Delta$ chirality with local $C_{3}$ symmetry [13-15]. In the absence of any templating effect there is nothing to direct the chirality to a specific handedness and a mixture of cages with multiple diastereoisomers may result. Whilst this can provide a route to chiral cages using achiral precursors, it is clearly not the most desirable synthetic strategy, as the resolution of these complexes can be challenging. Similar approaches can be employed to make cages with other geometries, such as cubes and octahedra, with similar issues associated with the chirality of tris-chelate metal centres [16-20]. Rather than local chirality around metal centres, it is desirable that the chirality is communicated to the overall cage, including the interior cavity. Strategies towards this include the use of chiral ligands to connect the metals together [21-23] or using supplementary non-bridging 
chiral ligands that cap the metal centres [24-26]. The major synthetic difficulty of these routes is the requirement for the ligands to be enantiomerically pure. There is also the issue that peripheral chiral groups, whilst reducing the symmetry of the cage as a whole, may not impact the interior space. One particularly relevant methodology has been to incorporate chiral functionalities at the ends of bis-chelate ligands, such that the molecular chirality dictates the $\Delta / \Lambda$ chirality around the resulting tris-chelated metal and therefore gives bulk enantiopurity in the cages [27-31]. Chiral coordination cages have recently been demonstrated to show enantioselective recognition [15,24], enantio- and chemo-selective catalysis [23,25], and recognition by fluorescence or luminescence methods [12]. Most pertinent to this current work are examples of using amino-acid based ligands to form chiral metallosupramolecular species containing copper paddlewheels, such as triangles and face-capped octahedra [32-34].

Recently we showed that it is possible to form charge-neutral, helical complexes of the form $\mathrm{Cu}_{4} \mathrm{~L}_{4}$ containing two copper paddlewheel motifs and four dicarboxylate ligands containing amino acids, as shown in Figure 1 [35]. A similar, smaller cage complex was reported around the same time by Chen et al. [36], and many achiral analogues are known [37-42]. Subsequently we have explored how changing the nature of the dicarboxylate affects the type and size of cage that can be obtained. Using a more rigid naphthalenediimide-based ligand we, and others, isolated $\mathrm{Cu}_{12} \mathrm{~L}_{12}$ octahedra $[43,44]$ and, by using a more rotationally unrestricted biphenyl core, we obtained $\mathrm{Cu}_{8} \mathrm{~L}_{8}$ "double-walled" squares [45]. It is also possible to isolate discrete catenanes using similar ligands [46], which are analogous to motifs observed in extended networks [47-50].
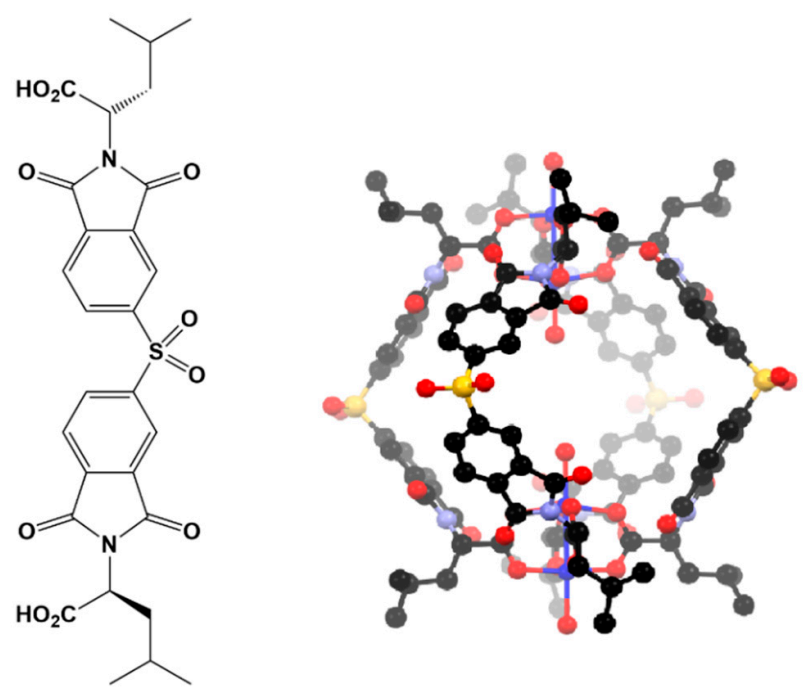

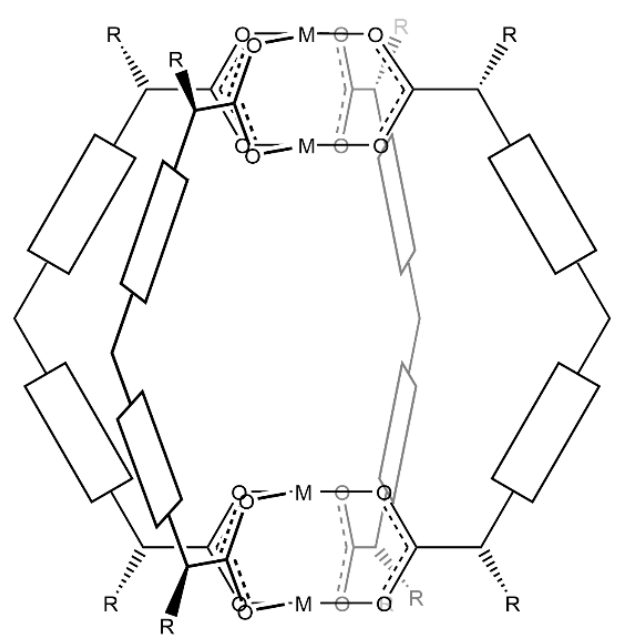

$\mathrm{H}_{2}$ LeuBPSD

Figure 1. The previously reported chiral diacid $\left(\mathrm{H}_{2} \mathrm{LeuBPSD}\right)$ and its $\mathrm{Cu}_{4} \mathrm{~L}_{4}$ cage complex alongside a schematic of the generic formulation of these helical cages, in which the cores of the ligands can be altered in attempts to construct analogous cages.

Herein we report the synthesis and structure of two enantiopure cages constructed using dicarboxylate ligands with different core groups, shown in Scheme 1. It is found that a longer, more curved ligand $\left(\mathbf{L 1}^{2-}\right)$ is able to form an analogue of the original $\mathrm{Cu}_{4} \mathrm{~L}_{4}$ cage, whereas a shorter and less flexible ligand $\left(\mathbf{L 2}^{2-}\right)$ clearly shows strain and is unable to form a fully closed cage complex. 

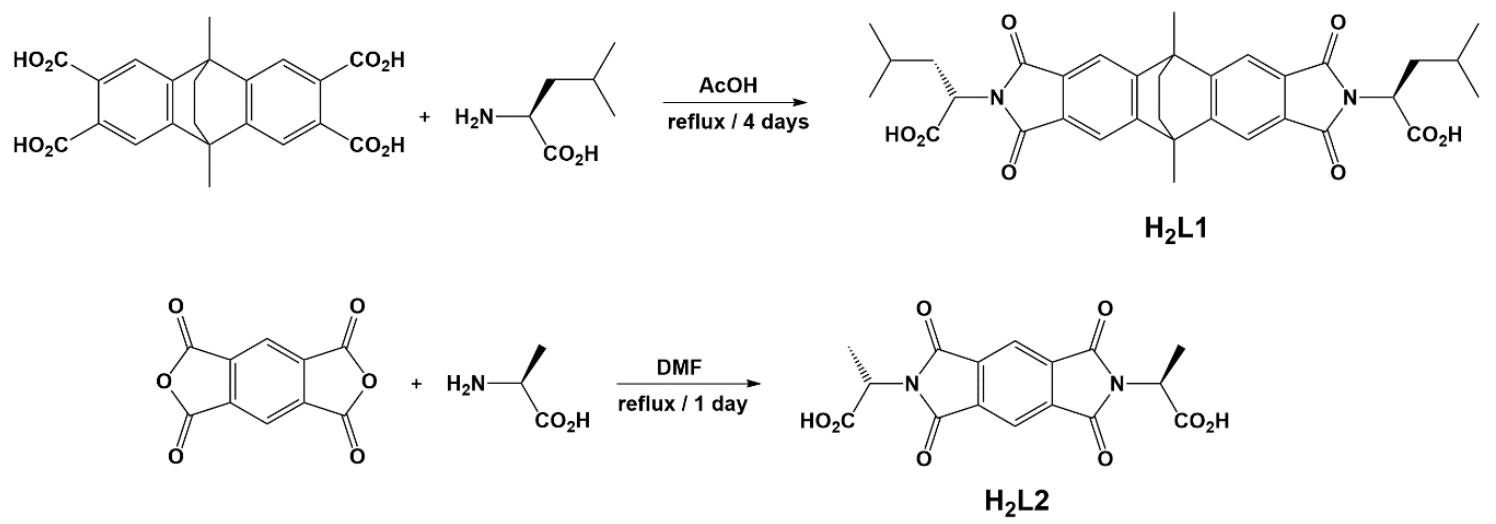

Scheme 1. Synthetic methodology for the two chiral diacids that have been used to synthesise cage complexes; the extended species $\mathbf{H}_{2} \mathbf{L} 1$ and the shorter $\mathbf{H}_{2} \mathbf{L} 2$.

\section{Materials and Methods}

\subsection{General Details}

All reagents and solvents were purchased from standard commercial suppliers and used as received, except for 9,10-dimethyl-9,10-dihydro-2,3,6,7-tetracrboxyl-9,10-ethanoanthracene, which was synthesised according to a literature preparation [51]. NMR spectra were obtained using a Bruker Avance 400 spectrometer operating at $400 \mathrm{MHz}\left({ }^{1} \mathrm{H}\right)$ or $100 \mathrm{MHz}\left({ }^{13} \mathrm{C}\right)$. FT-IR spectra were collected using an Agilent Carey 630 diamond attenuated total reflectance spectrometer. Mass spectra were collected using a Micromass platform electrospray mass spectrometer. TGA data were collected using a Mettler TGA/DSC 1 instrument ( $5 \mathrm{~K} / \mathrm{min}$ under $\mathrm{N}_{2}$ atmosphere). Elemental analyses were conducted at the London Metropolitan University.

\subsection{Synthesis and Characterisation}

Synthesis of $\mathbf{H}_{\mathbf{2}} \mathbf{L} \mathbf{1}$ : A suspension of L-leucine $(150 \mathrm{mg}, 1.15 \mathrm{mmol})$ and 9,10-dimethyl-9,10-dihydro2,3,6,7-tetracarboxyl-9,10-ethanoanthracene $(190 \mathrm{mg}, 0.463 \mathrm{mmol})$ was added to a round-bottomed flask with acetic acid $(20 \mathrm{~mL})$ and heated at $120^{\circ} \mathrm{C}$ for four nights, during which time all solids were taken into solution. After this time the light-yellow solution was poured over ice, forming a light-yellow precipitate, which was recovered by filtration, washed with water and dried in vacuo. Yield: $172.5 \mathrm{mg}$, $62 \%$. m.p. $195-198^{\circ} \mathrm{C}$. Found: $\mathrm{C}, 63.56 ; \mathrm{H}, 5.96 ; \mathrm{N}, 3.99 \% ; \mathrm{C}_{34} \mathrm{H}_{36} \mathrm{~N}_{2} \mathrm{O}_{8}$. Requires: $\mathrm{C}, 63.32 ; \mathrm{H}, 6.15 ; \mathrm{N}$, $3.89 \%$. $\delta \mathrm{H}\left(400 \mathrm{MHz}, d_{6}-\mathrm{DMSO}\right): 0.81\left(\mathrm{~m}, 12 \mathrm{H}, \mathrm{CH}_{2} \mathrm{CHMe}_{2}\right) ; 1.36\left(\mathrm{~m}, 2 \mathrm{H}, \mathrm{CH}_{2} \mathrm{CHMe}_{2}\right) ; 1.67(\mathrm{~s}, 4 \mathrm{H}$, $\left.\mathrm{CH}_{2} \mathrm{CH}_{2}\right) ; 1.8\left(\mathrm{~m}, 2 \mathrm{H}, \mathrm{CH}_{2} \mathrm{CHMe}_{2}\right) ; 2.21\left(\mathrm{~s}, 6 \mathrm{H}, \mathrm{Me}_{\text {core }}\right) ; 2.16\left(\mathrm{~m}, 2 \mathrm{H}, \mathrm{CH}_{2} \mathrm{CHMe}_{2}\right) ; 4.74\left(\mathrm{dd},{ }^{3} \mathrm{~J}=12\right.$, $\left.{ }^{3} J=4.2 \mathrm{~Hz}, 2 \mathrm{H}, \mathrm{NCH}\right) ; 7.78(\mathrm{~s}, 4 \mathrm{H}, \mathrm{ArH}) . \delta \mathrm{C}\left(100 \mathrm{MHz}, d_{6}-\mathrm{DMSO}\right): 21.1 ; 23.5 ; 26.1 ; 37.1 ; 43.4 ; 44.3$; 50.6; 116.6; 129.7; 152.8; 168.0; 171.3. $v_{\max } / \mathrm{cm}^{-1}: 2958 \mathrm{w} ; 2871 \mathrm{w} ; 1841 \mathrm{w} ; 17,700 \mathrm{~m} ; 1702 \mathrm{~s} ; 1617 \mathrm{~m} ; 1534 \mathrm{w}$; $1465 \mathrm{w} ; 1442 \mathrm{w} ; 1377 \mathrm{~s} ; 1321 \mathrm{w} ; 1250 \mathrm{~m} ; 1205 \mathrm{~m} ; 1155 \mathrm{~m} ; 1088 \mathrm{w} ; 991 \mathrm{w} ; 911 \mathrm{w} ; 869 \mathrm{w} ; 752 \mathrm{~m} . \mathrm{m} / \mathrm{z}$ (ES-): 504.1 ([M-Leu + OH] $]^{-}$, calculated for $\left.\mathrm{C}_{26} \mathrm{H}_{26} \mathrm{NO}_{8}{ }^{-}, 504.2\right), 100 \%$; $599.2\left([\mathrm{M}-\mathrm{H}]^{-}\right.$, calculated for $\mathrm{C}_{34} \mathrm{H}_{35} \mathrm{~N}_{2} \mathrm{O}_{8}{ }^{-}$, 599.2) $93 \%$.

Synthesis of $\mathbf{H}_{2} \mathbf{L} 2$ : The synthesis was based on a literature report with minor modifications [52]. Pyromellitic dianhydride $(0.707 \mathrm{~g}, 3.24 \mathrm{mmol})$ and L-alanine $(0.752 \mathrm{~g}, 8.44 \mathrm{mmol})$ were added to a round-bottomed flask with acetic acid $(40 \mathrm{~mL})$ and heated under reflux overnight, giving a colourless solution. Concentrated hydrochloric acid $(20 \mathrm{~mL})$ was added to the solution, which was allowed to concentrate by evaporation overnight to give a white powder. The product was collected by vacuum filtration, washed with cold water, added dropwise, and dried in air. Yield: $0.703 \mathrm{~g}, 60 \% .8 \mathrm{H}(400 \mathrm{MHz}$, $d_{6}$-DMSO): 1.59 (d, 6H, Me); 4.96 (q, 2H, NCH); 8.30 (s, 2H, ArH); 13.32 (s, 2H, CO $\left.{ }_{2} \mathrm{H}\right) .8 \mathrm{C}(100 \mathrm{MHz}$, $d_{6}$-DMSO): $15.14 ; 48.02 ; 118.45 ; 137.26 ; 165.92 ; 171.14 . v_{\max } / \mathrm{cm}^{-1}: 3570 \mathrm{w} ; 3146 \mathrm{w} ; 3007 \mathrm{w} ; 2953 \mathrm{w}$; $1758 \mathrm{w} ; 1702 \mathrm{~s} ; 1618 \mathrm{w} ; 1561 \mathrm{w} ; 1459 \mathrm{~m} ; 1383 \mathrm{~m} ; 1364 \mathrm{~m} ; 1304 \mathrm{~m} ; 1252 \mathrm{w} ; 1208 \mathrm{w} ; 1171 \mathrm{w} ; 1154 \mathrm{w} ; 1132 \mathrm{w}$; 
1104w; 1067m; 1018wm; 934m; 854m; 822w; 802w; 761w; 726m; 677w. m/z (ES-): 315.1 ([M-COO-H] $]^{-}$, calculated for $\mathrm{C}_{15} \mathrm{H}_{11} \mathrm{~N}_{2} \mathrm{O}_{6}{ }^{-}$, 315.1) $100 \%$; $359.1\left([\mathrm{M}-\mathrm{H}]^{-}\right.$, calculated for $\mathrm{C}_{16} \mathrm{H}_{11} \mathrm{~N}_{2} \mathrm{O}_{8}{ }^{-}$, 359.1) $20 \%$.

Synthesis of $\left[\mathrm{Cu}_{4}(\mathbf{L 1})_{4}(\mathrm{DMF})\left(\mathrm{OH}_{2}\right)_{3}\right] \cdot 3.5 \mathrm{DMF} \cdot 9.5 \mathrm{H}_{2} \mathrm{O}$ (compound 1): $\mathbf{H}_{2} \mathbf{L 1}(10 \mathrm{mg}, 16.7 \mu \mathrm{mol}$ ) and $\mathrm{Cu}_{2}(\mathrm{OAc})_{4}(6.0 \mathrm{mg}, 33.3 \mu \mathrm{mol})$ were added to DMF $(1 \mathrm{~mL})$ and sonicated to dissolve. The solution was heated at $85^{\circ} \mathrm{C}$ for two nights during which time light blue/green block-shaped crystals formed, which were recovered by vacuum filtration. Yield: $2.2 \mathrm{mg}, 61 \%$. Found: $\mathrm{C}, 56.04 ; \mathrm{H}, 5.58, \mathrm{~N}, 5.59 \%$; $\mathrm{C}_{139} \mathrm{H}_{149} \mathrm{~N}_{9} \mathrm{O}_{36} \mathrm{Cu}_{4} \cdot 3.5 \mathrm{DMF} \cdot 9.5 \mathrm{H}_{2} \mathrm{O}\left(\left[\mathrm{Cu}_{4}(\mathbf{L 1})_{4}\right.\right.$ (DMF) $\left.\left.\left(\mathrm{OH}_{2}\right)_{3}\right] \cdot 3.5 \mathrm{DMF} \cdot 9.5 \mathrm{H}_{2} \mathrm{O}\right)$. Requires: C, 56.14; $\mathrm{H}, 6.02 ; \mathrm{N}, 5.31 \%$. $v_{\max } / \mathrm{cm}^{-1}: 2955 \mathrm{w} ; 2869 \mathrm{w} ; 1771 \mathrm{w} ; 1709 \mathrm{~s} ; 1637 \mathrm{~m} ; 1465 \mathrm{w} ; 1411 \mathrm{~m} ; 1377 \mathrm{~s} ; 1351 \mathrm{~m}$; 1259w; 1204w; 1156w; 1101w; 1062w; 992w; 913w; 870w; 805w; 771w; 755m; 729w; 660m. m/z (ES+): $2649.7(\text { cage }+\mathrm{H})^{+}$, calculated for $\mathrm{C}_{136} \mathrm{H}_{136} \mathrm{Cu}_{4} \mathrm{~N}_{8} \mathrm{O}_{32}{ }^{+}, 2647.645 ; 2708.7$ (cage $\left.+\mathrm{H}_{2} \mathrm{O}+\mathrm{MeCN}+\mathrm{H}\right)^{+}$, calculated for $\mathrm{C}_{138} \mathrm{H}_{141} \mathrm{Cu}_{4} \mathrm{~N}_{9} \mathrm{O}_{33}{ }^{+}, 2706.683$. TGA: On-set, $70{ }^{\circ} \mathrm{C}$, mass loss $=10 \%$ (calculated $11.8 \%$ for loss of two non-coordinated $\mathrm{H}_{2} \mathrm{O}$ and 4.5 DMF molecules and all coordinated solvent); decomp, $350{ }^{\circ} \mathrm{C}$.

Synthesis of $\left[\mathrm{Co}_{8}(\mathbf{L 2})_{8}(\mathrm{DABCO})_{3}\left(\mathrm{OH}_{2}\right)_{8}\right]$-solvent (compound 2): $\mathbf{H}_{\mathbf{2}} \mathbf{L 2}(10 \mathrm{mg}, 28 \mu \mathrm{mol}), \mathrm{DABCO}$ $(1.6 \mathrm{mg}, 14 \mu \mathrm{mol})$, and $\mathrm{Co}\left(\mathrm{NO}_{3}\right)_{2} \cdot 6 \mathrm{H}_{2} \mathrm{O}(8.1 \mathrm{mg}, 28 \mu \mathrm{mol})$ were added to DMF $(2 \mathrm{~mL})$ and sonicated to dissolve. The solution was heated at $100{ }^{\circ} \mathrm{C}$ for three nights during which time crystalline royal blue plates formed. Only one or two small single crystals formed, preventing bulk analysis. $\mathrm{m} / \mathrm{z}(\mathrm{ES}-)$ : $955.9\left(\left[\mathrm{Co}_{4}(\mathrm{~L} 2)_{4}(\mathrm{DABCO})\left(\mathrm{H}_{2} \mathrm{O}\right)_{3}(\mathrm{OH})\right] \mathrm{NO}_{3}\right)^{2-}$, calculated for $\mathrm{C}_{70} \mathrm{H}_{59} \mathrm{Co}_{4} \mathrm{~N}_{11} \mathrm{O}_{39}{ }^{2-}$, 956.0; $1841.9\left(\left[\mathrm{Co}_{4}(\mathbf{L} 2)_{4}(\mathrm{DABCO})\right] \mathrm{NO}_{3}\right)^{-}$, calculated for $\mathrm{C}_{70} \mathrm{H}_{52} \mathrm{Co}_{4} \mathrm{~N}_{11} \mathrm{O}_{35}{ }^{-}$, 1842.0.

\subsection{X-ray Crystallography}

Single crystal X-ray diffraction data were obtained using the MX1 beamline at the Australian Synchrotron, operating at $17.4 \mathrm{keV}(\lambda=0.7108 \AA)$ [53]. The data were collected at $100 \mathrm{~K}$ using an open-flow $\mathrm{N}_{2}$ cryostream. The data collections were controlled using the software BluIce [54]. The initial data indexing and reduction was conducted using the XDS software suite [55]. Structures were solved using SHELXT and refined against $\mathrm{F}^{2}$ by standard least squares methods using SHELXL-2018 [56,57]. The programs X-Seed or Olex2 were used as a graphical interface to the SHELX program suite [58,59]. Non-hydrogen atoms were refined using an anisotropic model, except for a few exceptions, as shown in Appendix A. All hydrogen atoms were placed in calculated positions and refined using a riding model. The data were treated with the SQUEEZE routine of PLATON to account for regions of poorly ordered solvent, as shown in Appendix A [60]. Crystallographic data have been deposited in the Cambridge Structural Database (2006794-2006795) and can be obtained from www.ccdc.cam.ac.uk. Special refinement details are provided in both Appendix A and CIF files.

\section{Results}

\subsection{Design and Synthesis of Ligands}

Two dicarboxylate ligands, containing amino acid residues, were synthesized as analogues of the sulfone-diphthalimide species that we previously used to form helical $\left[\mathrm{Cu}_{4}(\operatorname{LeuBPSD})_{4}\right]$ cages [35]. The two core groups used represent a longer, bent ligand using a 9, 10-dimethylethanoanthracene derivative $\left(\mathbf{H}_{\mathbf{2}} \mathbf{L} 1\right)$ and a shorter, more rigid ligand using a pyromellitic acid building block $\left(\mathbf{H}_{2} \mathbf{L} 2\right)$. Pyromelliticdiimides are well known in the literature. For example, isophthalate derivatives have been used in MOFs with high sorption capacities [60], dipyridyl derivatives have been used in a number of coordination polymers [61-64], as have thioether derivatives [65], and the diimide core has also been incorporated into a number of macrocycles and receptors [66-71]. Pyromelliticdiimides based on amino acid derivatives have been reported in hydrogen-bonding systems and coordination polymers [72-79]. The applicability of the dihydroanthracene core group is hinted at in the literature with metallocages reported containing shorter ligands using bicyclooctene as a core group [36]; the ethanodihydroanthracene moiety can be viewed as an analogous, extended core group with the same geometry. This core group, 
as a bis-catechol, has been used in the synthesis of a uranyl lantern-type cage, discrete silane assemblies, and a $\mathrm{Mn}_{12}$ metallacycle [80-82].

9,10-Dimethyl-9,10-ethanoanthracene-2,3,6,7-tetracarboxylic acid was synthesised in three steps by a literature procedure [51]. A low yielding cyclisation step proved rather prohibitive for the large scale synthesis of this material. The tetra-acid was reacted with leucine in acetic acid under reflux for four nights, resulting in $\mathbf{H}_{\mathbf{2}} \mathbf{L} \mathbf{1}$ being isolated as a pale, yellow solid, as shown in Scheme 1. $\mathbf{H}_{\mathbf{2}} \mathbf{L} 2$ was synthesized by the slight amendment of a known method [52].

\subsection{Synthesis and Structure of Helicate-Type Complexes}

The reaction of $\mathbf{H}_{\mathbf{2}} \mathbf{L} \mathbf{1}$ with copper acetate at an elevated temperature in DMF yielded a blue/green crystalline material suitable for analysis by single crystal X-ray diffraction (compound $\mathbf{1}$ ). The structure, solved and refined in the orthorhombic setting $C 222_{1}$, reveals the anticipated lantern-type helical complex, $\left[\mathrm{Cu}_{4}(\mathbf{L 1})_{4}(\text { solvent })_{4}\right]$. The asymmetric unit contains one half of a cage (comprising one copper paddlewheel and one and two half ligands). The overall cage has the two halves related by a two-fold proper rotation that bisects the mid points of two ethanoanthracene core groups. The external facing sites of the two paddlewheels are occupied by aqua ligands. The internal sites are occupied by one DMF and one aqua ligand, which are disordered within the crystal structure. The cage has an internal $\mathrm{Cu}$...Cu distance of 9.225(3) $\AA$, substantially longer than the prior sulfone-based analogue (ca. $7.2 \AA$ ). Taking the internal cavity, minus coordinated solvent, as an approximate prolate spheroid, the internal volume is ca. $380 \AA^{3}$. The persistence of the cage in solution was confirmed by mass spectrometry as a $\mathrm{H}_{2} \mathrm{O} / \mathrm{MeCN}$ solvated complex. The cage does not possess a $\mathrm{C}_{4}$ axis along the $\mathrm{Cu}_{2} \cdots \mathrm{Cu}_{2}$ vector, with the paddlewheels themselves not aligned, although a pseudo four-fold rotation can be seen in Figure 2 on the left. The complex has a helical pitch that results in the ligands coordinating at sites $90^{\circ}$ apart between the two paddlewheels, analogous to the structures observed in studies of the smaller sulfone-based ligand. It seems that the use of a longer ligand results in a complex that is somewhat less regular in shape, presumably due to the enhanced flexibility of the core group, yet the overall structural design is retained. The arrangement around the paddlewheels is not distorted, with imide $\mathrm{N} \cdots \mathrm{N}$ distances between adjacent ligands in the range 6.29-6.39 $\AA$.
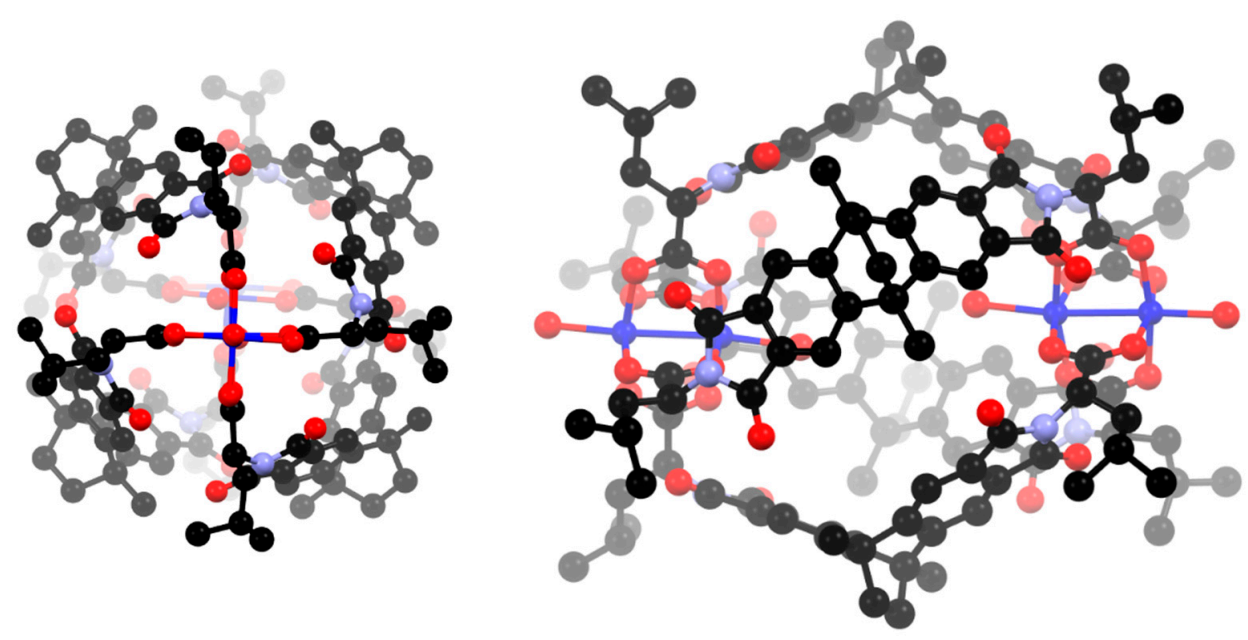

Figure 2. Two views of the cage complex $\left[\mathrm{Cu}_{4}(\mathbf{L 1})_{4}\right]$ showing only the coordinating oxygen atoms in the solvent positions. Hydrogen atoms are omitted for clarity.

The reaction of $\mathbf{H}_{\mathbf{2}} \mathbf{L} \mathbf{2}$ with cobalt nitrate at an elevated temperature in DMF yielded a few royal blue crystals (compound 2) that were suitable to obtain moderate resolution single crystal X-ray diffraction data using synchrotron radiation. Unfortunately, the yields were so low as to prohibit bulk analysis other than by mass spectrometry of the reaction solution, as described below. The crystal structure was solved and refined in the orthorhombic space group $P 2{ }_{1}{ }_{2} 2$ and contains halves of two 
crystallographically unique complexes in the asymmetric unit. The nature of the complex is somewhat complicated to determine unambiguously due to crystallographic disorder, with several possible sites for (de)protonation. However, the gross formulation is clear as a "dumbbell-like" complex consisting of two pseudo- $\left[\mathrm{Co}(\mathbf{L} 2)_{4}(\mathrm{DABCO})\right]$ units, bridged by a central DABCO ligand with an overall formulation of $\left[\left\{\mathrm{Co}_{4}(\mathbf{L} 2)_{4}(\mathrm{DABCO})\left(\mathrm{H}_{2} \mathrm{O}\right)_{\times}\right\}_{2}(\mathrm{DABCO})\right]$, as shown in Figure 3. The two crystallographically unique dumbbell complexes both contain an axis of rotation passing through the central DABCO ligand, meaning that the two ends are symmetry equivalent. The two complexes appear to be compositionally identical, although the crystallographic disorder is different and, for brevity, only the complex with the more minor disorder is discussed below—see Appendix A for further crystallographic discussion.

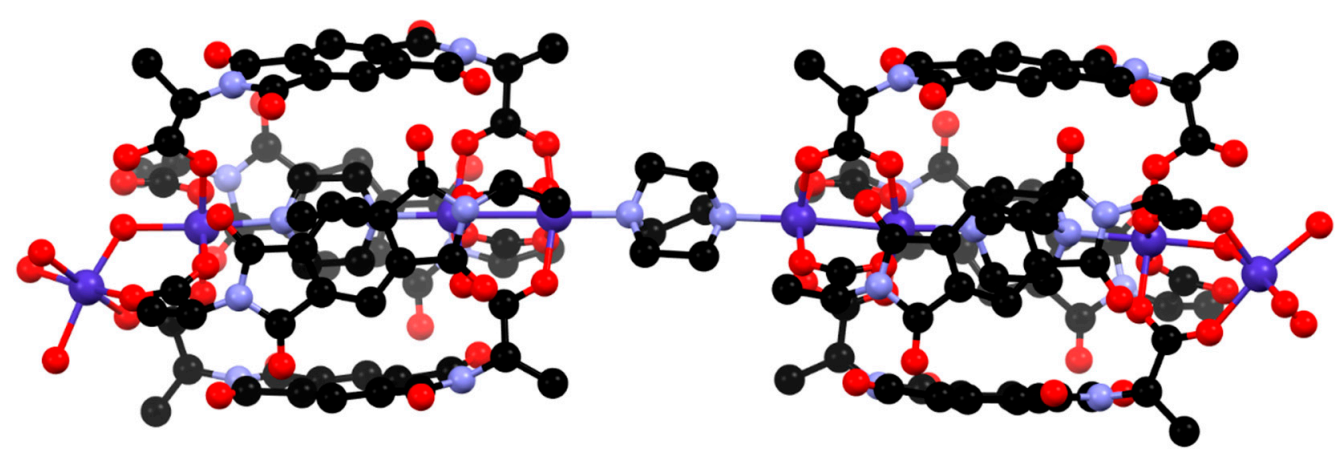

Figure 3. The "dumbbell-type" complex $\left[\left\{\mathrm{Co}_{4}(\mathrm{~L} 2)_{4}(\mathrm{DABCO})\left(\mathrm{H}_{2} \mathrm{O}\right)_{4}\right\} 2(\mathrm{DABCO})\right]$. Hydrogen atoms are omitted for clarity.

In both complexes, there is one major component of the disorder. The ends of this dumbbell complex are a variation of the $\mathrm{M}_{4} \mathrm{~L}_{4}$ cage motif, with the cage closed by the expected paddlewheel motif at one end (that closest to the centre of the complex) yet capped by an unusual coordination environment at the other end (the far ends of the complex, Figure 4). The two ends are bridged by a DABCO ligand within the cavity of the cage. The $\mathrm{Co}_{2}$ unit at the end of the complex consists of two octahedral cobalt ions. The one nearest the centre of the cavity is coordinated by four carboxylate oxygen atoms and the DABCO ligand, as expected, but also by an aqua ligand. This aqua ligand forms a bridge to the second Co ion, which is coordinated by only two of the carboxylate groups and has three aqua ligands to complete its coordination sphere. The remaining two carboxylates of this $\mathrm{M}_{4} \mathrm{~L}_{4}$ unit are non-coordinating. Ambiguity arises from the nature of the bridging ligand $\left(\mathrm{H}_{2} \mathrm{O}, \mathrm{OH}^{-}\right.$, or $\mathrm{O}^{2-}$ ) and the protonation state of the carboxylate groups (i.e., carboxylate vs. carboxylic acid); bond lengths and crystal colour confirm the oxidation state of the metal ions as cobalt (II). The distances between the bridging oxygen atom and non-coordinated oxygen atoms of the carboxylate groups are ca. $2.7 \AA$ and the angle subtended at the bridging oxygen atom is $104^{\circ}$. These measurements strongly suggest that this is a $\mu_{2}$ bridging $\mathrm{H}_{2} \mathrm{O}$, acting as a hydrogen bond donor to the two carboxylates, and therefore has the formula $\left[\left\{\mathrm{Co}_{4}(\mathbf{L} 2)_{4}(\mathrm{DABCO})\left(\mathrm{H}_{2} \mathrm{O}\right)_{4}\right\}_{2}(\mathrm{DABCO})\right]$. There are minor components in both instances for which solvation within the coordination sphere cannot be fully resolved due to their small occupancy and proximity to heavier elements. What can be found suggests tetrahedral or non-standard coordination geometries for these positions, supported by the observation of crystal colour (blue), which suggests some amount of tetrahedral $\mathrm{Co}^{\mathrm{II}}$ is present.

The two crystallographically unique complexes are different in terms of the distortion of the cage, presumably a consequence of accommodating the disorder around the terminal $\mathrm{Co}_{2}$ units. One useful way of measuring this distortion is by the distances between the imide nitrogen atoms of the adjacent $\mathbf{L} 2$ ligands. The complex containing two disordered Co positions adopts a "pinched" conformation, with three $\mathrm{N} \cdots \mathrm{N}$ distances of $6.2 \AA$ and one of $7.2 \AA$ (measured at both ends of the cage). The measurements are the same at both ends of the cage (i.e., there is no enhanced distortion of the $\mathrm{N} \cdots \mathrm{N}$ distance at the non-paddlewheel node). The result is that there is a larger "window" on one face of the cage. The other complex, with three disordered cobalt positions, contains N...N distances in the range 6.19-6.54 $\mathrm{A}$, 
again with no significant difference between the distances at the two ends of the cage. There is some evidence of strain in the cages by examination of the $\mathrm{Co}-\mathrm{O}$ bond lengths and the appreciable bowing of the L2 ligands. The average of the Co-O bond lengths in the two paddlewheels is $2.03 \AA$, whereas those in the pseudo-paddlewheels (measured only at the bottoms of these motifs, which are analogous to a paddlewheel) average $2.06 \AA$. Whilst only a slight difference, this does suggest some strain at the extremities of the complexes. The $\mathbf{L} 2$ ligands are significantly bowed away from planarity, which is normally observed for pyromelliticdiimides [60-79]. Calculating a mean plane through the $C$ and $\mathrm{N}$ atoms of the pyromelliticdiimide core of $\mathbf{L} 2$ highlights that there is significant deviation away from planarity, with the nitrogen atoms ca. $0.2 \AA$ removed from the plane. The carbon atoms of the alanine groups (formerly the $\alpha$-carbon of the amino acid) are even further removed from the plane by $0.55-0.90 \AA$, highlighting the convex nature of the ligands in this complex and the apparent strain.

ESI mass spectrometry of the reaction solution shows both singly- and doubly-charged signals corresponding to one end of the dumbbell complex, $\left[\mathrm{Co}_{4}(\mathrm{~L} 2)_{4}(\mathrm{DABCO})\right]$ with some degree of solvation, indicating that the cage is stable in solution, although not the dumbbell complex (not unexpected, given the rather curious nature of the complex). A signal for a 1-ion matches for $\left[\mathrm{Co}_{4}(\mathbf{L} 2)_{4}(\mathrm{DABCO}) \mathrm{NO}_{3}\right.$, suggesting the that the complex can exist in a non-solvated form, presumably with the implication that the paddlewheels are fully closed. The 2-ion has a $\mathrm{m} / \mathrm{z}$ value that corresponds to $\left[\mathrm{Co}_{4}(\mathbf{L} 2)_{4}(\mathrm{DABCO})\left(\mathrm{H}_{2} \mathrm{O}\right)_{3}(\mathrm{OH})\right] \mathrm{NO}_{3}$, which matches with the formulation seen in the crystal structure (with the deprotonation of one water). These results suggest that the cage complex is retained in the bulk, but not the dumbbell complex.
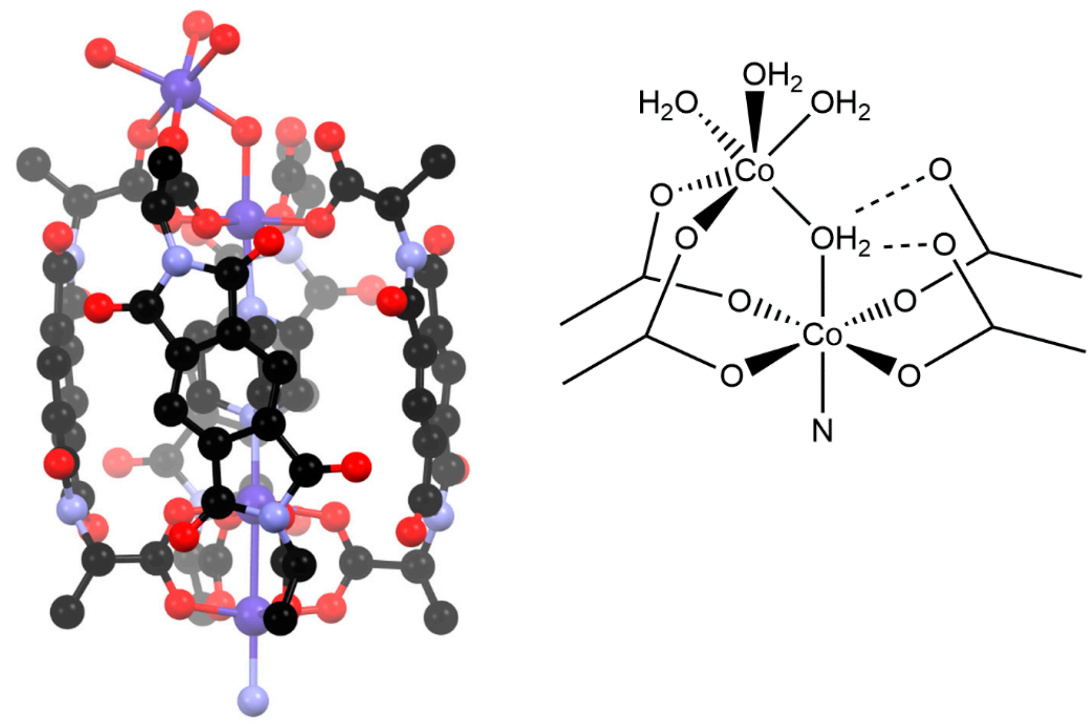

Figure 4. One end of the "dumbbell-type" complex shown in Figure 3, in which the coordination environment of the terminal end (top of picture) and the appreciable bowing of the L2 ligands can be seen (hydrogen atoms are omitted for clarity) alongside a schematic of the unusual terminal coordination environment.

\section{Discussion}

It is well known that copper forms a paddlewheel motif when combined with carboxylates, as reported for a large number of cage complexes [32-42]. For this reason, it has been the mainstay of our efforts to form lantern-type cages. Unfortunately, we were only able to isolate an identifiable product using $\mathrm{H}_{2} \mathrm{~L} \mathbf{1}$ in combination with copper, with the reactions using $\mathrm{H}_{2} \mathrm{~L} 2$ and copper giving solutions that could not be properly characterized. NMR, in particular, proves challenging, due to the paramagnetism of the copper(II) ion. Perhaps it can be reasoned that a copper (II) analogue of compound 2 would not form, as the coordination environment is not ideally suited to the coordination preferences of the ion (presumably necessitating the $\mathrm{N}$-donor DABCO ligand in a Jahn-Teller distorted axial position). 
Similarly, a cobalt (II) analogue of compound 1 could not be prepared, again with characterization issues regarding paramagnetic nuclei. Cobalt-carboxylate paddlewheels are somewhat rarer in the literature than their copper counterparts, and perhaps the DABCO ligand assists in stabilizing the paddlewheel that we do observe. Whilst it is unfortunate that direct comparisons between complexes with identical metal ions can be made, there does appear to be some rationale for why this may be the case.

The cage-type complexes obtained using $\mathrm{H}_{2} \mathrm{~L} 1$ and $\mathrm{H}_{2} \mathrm{~L} 2$ demonstrate both the versatility of the synthetic approach and its limitations. It is clear that there is a drive towards the formation of lantern-type structures, a well-known $\mathrm{M}_{4} \mathrm{~L}_{4}$ motif for achiral cages (in which rigid ligands connect the paddlewheels in a mesocate-type arrangement with the ligands running straight between the paddlewheels), but one which is less explored for helical complexes [35-42]. The $\left[\mathrm{Cu}_{4}(\mathbf{L 1})_{4}(\text { solvent })_{4}\right]$ cage forms as anticipated. Whilst the conformation of the cage is distorted away from an idealized $\mathrm{C}_{4}$ symmetric species in the solid-state structure, it is likely that there is some structural relaxation in solution (one must always be careful not to extrapolate solution behaviour from a static crystallographic model).

It seems that the anticipated $\mathrm{M}_{4} \mathrm{~L}_{4}$-type motif in compound $\mathbf{2}$ is being disrupted due to the use of a shorter and more rigid ligand than $\mathbf{H}_{\mathbf{2}} \mathbf{L} \mathbf{1}$ and those used in previous studies. Although the change is most pronounced at the terminal coordination sites, there are other features in the complex, namely, the extreme bowing of the ligands and subtle changes to Co-O bond lengths, which indicate that the system is under some strain. Clearly the rigidity of the ligand, combined with size, has a substantial impact. The earlier report by Chen et al. demonstrated that short diimides can be used to form cages, in this case using a bicyclooctene core [36]. Given the similarity in length between bicyclooctene and phenyl cores, it is therefore evident that the rigidity of the pyromelliticdiimide is the governing factor in limiting the formation of a complete lantern-type cage. Perhaps this is also borne out by our published use of larger, NDI-based ligands that formed octahedral cages, as the rigidity presumably disfavoured the formation of $\mathrm{M}_{4} \mathrm{~L}_{4}$ complexes [43,44]. The internal bridging DABCO may help to stabilize the cages in $\left[\left\{\mathrm{Co}_{4}(\mathbf{L} 2)_{4}(\mathrm{DABCO})\left(\mathrm{H}_{2} \mathrm{O}\right)_{4}\right\} 2(\mathrm{DABCO})\right]$. Whilst it is far from definitive, we were unable to obtain any crystalline material using $\mathrm{H}_{2} \mathrm{~L} 2$ in the absence of DABCO, other than analogues of previously reported coordination polymers, thus suggesting that the role of DABCO is essential [79].

\section{Conclusions}

In our efforts to expand the scope of a generalized approach to forming chiral lantern-type cages, complexes containing paddlewheel and "pseudo-paddlewheel" motifs were synthesized using the chiral diacids $\mathbf{H}_{2} \mathbf{L} 1$ and $\mathbf{H}_{2} \mathbf{L} 2$. The $\left[\mathrm{Cu}_{4}(\mathbf{L 1})_{4}\right]$ cage adopts the anticipated lantern-type helical structure with a larger central cavity than our previously reported sulfone-based cage (ca. $380 \AA^{3}$ ). The cages within the $\left[\left\{\mathrm{Co}_{4}(\mathbf{L} 2)_{4}(\mathrm{DABCO})\left(\mathrm{H}_{2} \mathrm{O}\right)_{\times}\right\}_{2}(\mathrm{DABCO})\right]$ complexes retain the overall general design but are clearly under some strain, highlighted by the broken paddlewheels at their extremities. These results show promising initial steps towards a generic approach for the formation of enantiopure helical compounds, with the condition/limitation that the core group of the ligand contains the correct angular preference and flexibility. These results are encouraging to our ongoing efforts to expand the structural types accessible from this general approach.

Author Contributions: Conceptualization, D.R.T.; methodology, S.A.B. and D.R.T.; investigation, S.A.B., W.C., B.K.G. and D.R.T.; writing — original draft preparation, D.R.T.; writing—review and editing, S.A.B., W.C., B.K.G. and D.R.T.; supervision, D.R.T.; project administration, D.R.T.; funding acquisition, D.R.T. All authors have read and agreed to the published version of the manuscript.

Funding: This research was partly funded by the Australian Research Council, grant number FT120100300.

Acknowledgments: Part of this work was conducted using the MX1 beamline at the Australian Synchrotron, part of ANSTO.

Conflicts of Interest: The authors declare no conflict of interest. The funders had no role in the design of the study; in the collection, analyses, or interpretation of data; in the writing of the manuscript, or in the decision to publish the results. 


\section{Appendix A}

\section{Crystallographic Data and Special Refinement Details}

Crystal data for 1: $\mathrm{C}_{139} \mathrm{H}_{149} \mathrm{Cu}_{4} \mathrm{~N}_{9} \mathrm{O}_{36}, \mathrm{M}=2775.82$, clear green block, $0.02 \times 0.01 \times 0.01 \mathrm{~mm}^{3}$, orthorhombic, space group $C 222_{1}, a=17.052(3) \AA, b=27.160(5) \AA, c=37.010(7) \AA, V=17,140(6) \AA^{3}$, $\mathrm{Z}=4, \mathrm{D}_{\mathrm{c}}=1.076 \mathrm{~g} / \mathrm{cm}^{3}, \mathrm{~F}_{000}=5800$, ADSC Quantum 210r, synchrotron radiation (MX1, Australian Synchrotron), $\lambda=0.7108 \AA, \mathrm{T}=100.0 \mathrm{~K}, 2 \theta_{\max }=52.9^{\circ}, 45,853$ reflections collected, 14,407 unique $\left(R_{\text {int }}=0.1457\right)$. Final GooF $=1.029, \mathrm{R} 1=0.0861, \mathrm{wR} 2=0.2282, \mathrm{R}$ indices based on 7756 reflections with $\mathrm{I}>2 \sigma(\mathrm{I})$ (refinement on $\mathrm{F}^{2}$ ), 884 parameters, 178 restraints. Lp and absorption corrections applied, $\mu=0.554 \mathrm{~mm}^{-1}$.

Data for compound 1 were treated using the SQUEEZE routine of PLATON, finding two large voids per unit cell and several smaller pockets. Density accounting for $292 \mathrm{e}^{-}$was located per cage complex. This tentatively accounts for $15 \mathrm{H}_{2} \mathrm{O}$ and 3.5 DMF molecules, more than is found by TGA, although solvent is likely lost in handling and transit. A number of restraints were required for bond lengths and displacement elipsoids, primarily those associated with the iosbutyl chains and disordered solvent sites, as shown in the information embedded in CIF file.

Crystal data for 2: $\mathrm{C}_{146} \mathrm{H}_{124} \mathrm{Co}_{8} \mathrm{~N}_{22} \mathrm{O}_{72}, \mathrm{M}=3810.10$, blue plate, $0.16 \times 0.10 \times 0.04 \mathrm{~mm}^{3}$, orthorhombic, space group $\mathrm{P} 2{ }_{1} 2{ }_{1} 2, \mathrm{a}=35.489(7) \AA, \mathrm{b}=21.851(4) \AA, \mathrm{c}=25.061(5) \AA, \mathrm{V}=19,434(7) \AA^{3}, \mathrm{Z}=4, \mathrm{D}_{\mathrm{c}}=1.302 \mathrm{~g} / \mathrm{cm}^{3}$, $\mathrm{F}_{000}=7784$, ADSC Quantum 210r, synchrotron radiation (MX1, Australian Synchrotron), $\lambda=0.7108 \AA$, $\mathrm{T}=100.0 \mathrm{~K}, 2 \theta_{\max }=50.0^{\circ}, 125,332$ reflections collected, 34,118 unique $\left(\mathrm{R}_{\mathrm{int}}=0.0826\right)$. Final $\mathrm{GooF}=1.023$, $\mathrm{R} 1=0.0859, \mathrm{wR} 2=0.2263, \mathrm{R}$ indices based on 27,536 reflections with $\mathrm{I}>2 \sigma(\mathrm{I})\left(\right.$ refinement on $\left.\mathrm{F}^{2}\right)$, 2356 parameters, 54 restraints. Lp and absorption corrections applied, $\mu=0.753 \mathrm{~mm}^{-1}$.

The structural model contains significant disorder at the terminal positions of the complexes, and the data were treated using SQUEEZE, due to large spaces between the complexes where no model could be applied. However, no restraints of any kind (other than some restraints for disordered DABCO ligands) were applied to the refinement, and the structure is reported in an unadulterated form. All atoms, other than those associated with the minor components of the disorder, were located and freely refined with anisotropic models. No hydrogen atoms were modelled on the aqua ligands, but these are included in the molecular formula. Some large displacement parameters remain in the model, indicative of disorder in the ligands that could not be modelled. The final refinement has a non-zero Flack parameter, 0.088 (7), which is likely a result of slightly low quality data and large areas of disorder in the model.

The complex containing atoms Co1-Co4 contains three disordered Co positions at the ends, refined with 50:30:20 occupancies by means of equalizing the $\mu_{\text {iso }}$ averaged displacement parameters. There is some evidence of a very minor fourth position ( $Q$ peak of apparent Co site $<2 \mathrm{e}^{-}$) for which modelling was not attempted. The aqua ligands were located for the major occupancy site and refined isotropically; those belonging to the minor occupancy positions could not be located. Both DABCO ligands contained disorder that was modelled with fixed 50:50 occupancies.

The complex containing atoms $\mathrm{Co} 5-\mathrm{Co} 8$ contains two disordered Co positions at the ends, refined with 70:30 occupancies by means of equalizing the $\mu_{\text {iso }}$ averaged displacement parameters. Aqua ligands to complete the octahedral coordination sphere were all located for the major component (O only, isotropic model). The central DABCO ligand of the dumbbell contains disorder with two $\mathrm{C}_{2} \mathrm{H}_{4}$ groups modelled with fixed 50:50 occupancies, and one $\mathrm{C}_{2} \mathrm{H}_{4}$ group is modelled with large displacement parameters, as a disordered model could not be satisfactorily refined. Two carboxylate oxygen atoms (O44 and $\mathrm{O} 52)$ are modelled as disordered (30:70) in line with being either coordinated to the minor occupancy cobalt position or not. 


\section{References}

1. Cram, D.J.; Cram, J.M. Container Molecules and Their Guests; Royal Society of Chemistry: Cambridge, UK, 1997.

2. Chakrabarty, R.; Mukherjee, P.S.; Stang, P.J. Supramolecular Coordination: Self-Assembly of Finite Two- and Three-Dimensional Ensembles. Chem. Rev. 2011, 111, 6810-6918. [CrossRef] [PubMed]

3. Zarra, S.; Wood, D.M.; Roberts, D.A.; Nitschke, J.R. Molecular containers in complex chemical systems. Chem. Soc. Rev. 2015, 44, 419-432. [CrossRef] [PubMed]

4. Friese, V.A.; Kurth, D.G. From coordination complexes to coordination polymers through self-assembly. Curr. Opinon Colloid Interface Sci. 2009, 14, 81-93. [CrossRef]

5. Vardhan, H.; Yusubov, M.; Verpoort, F. Self-assembled metal-organic polyhedra: An overview of various applications. Coord. Chem. Rev. 2016, 306, 171-194. [CrossRef]

6. Saha, M.L.; De, S.; Pramanik, S.; Schmittel, M. Orthogonality in discrete self-assembly—Survey of current concepts. Chem. Soc. Rev. 2013, 42, 6860-6909. [CrossRef]

7. Northrop, B.H.; Zheng, Y.-R.; Chi, K.-W.; Stang, P.J. Self-Organization in Coordination-Driven Self-Assembly. Acc. Chem. Res. 2009, 42, 1554-1563. [CrossRef]

8. Casini, A.; Woods, B.; Wenzel, M. The Promise of Self-Assembled 3D Supramolecular Coordination Complexes for Biomedical Applications. Inorg. Chem. 2017, 56, 14715-14729. [CrossRef]

9. Chen, L.-J.; Yang, H.-B.; Shionoya, M. Chiral metallosupramolecular architectures. Chem. Soc. Rev. 2017, 46, 2555-2576. [CrossRef]

10. Clegg, J.K.; McMurtrie, J.C. Chiral Metallosupramolecular Polyhedra. In Chirality in Supramolecular Assemblies: Causes and Consequences; Keene, F.R., Ed.; John Wiley \& Sons: Chichester, UK, 2016; pp. 218-256.

11. Pan, M.; Wu, K.; Zhang, J.-H.; Su, C.-Y. Chiral metal-organic cages/containers (MOCs): From structural and stereochemical design to application. Coord. Chem. Rev. 2019, 378, 333-349. [CrossRef]

12. Zhang, J.-H.; Xie, S.-M.; Zi, M.; Yuan, L.-M. Recent advances of application of porous molecular cages for enantioselective recognition and separation. J. Sep. Sci. 2020, 43, 134-149. [CrossRef]

13. Saalfrank, R.W.; Glaser, H.; Demleitner, B.; Hampel, F.; Chowdhry, M.M.; Schünemann, V.; Trautwein, A.X.; Vaughan, G.B.M.; Yeh, R.; Davis, A.V.; et al. Self-Assembly of Tetrahedral and Trigonal Antiprismatic Clusters $\left[\mathrm{Fe}_{4}\left(\mathrm{~L}^{4}\right)_{4}\right]$ and $\left[\mathrm{Fe}_{6}\left(\mathrm{~L}^{5}\right)_{6}\right]$ on the Basis of Trigonal Tris-Bidentate Chelators. Chem. Eur. J. 2002, 8, $493-497$. [CrossRef]

14. Zhao, C.; Toste, F.D.; Raymond, K.N.; Bergman, R.G. Nucleophilic Substitution Catalyzed by a Supramolecular Cavity Proceeds with Retention of Absolute Stereochemistry. J. Am. Chem. Soc. 2014, 136, 14409-14412. [CrossRef] [PubMed]

15. He, Y.-P.; Yuan, L.-B.; Song, J.-S.; Chen, G.-H.; Lin, Q.; Li, C.; Zhang, L.; Zhang, J. Optical Resolution of the Water-Soluble $\mathrm{Ti}_{4}$ (embonate) 6 Cages for Enantioselective Recognition of Chiral Drugs. Chem. Mater. 2018, 30, 7769-7775. [CrossRef]

16. Browne, C.; Brenet, S.; Clegg, J.K.; Nitschke, J.R. Solvent-Dependent Host-Guest Chemistry of an $\mathrm{Fe}_{8} \mathrm{~L}_{12}$ Cubic Capsule. Angew. Chem. Int. Ed. 2013, 52, 1944-1948. [CrossRef] [PubMed]

17. Yang, Y.; Wu, Y.; Jia, J.-H.; Zheng, X.-Y.; Zhang, Q.; Xiong, K.-C.; Zhang, Z.-M.; Wang, Q.-M. Enantiopure Magnetic Heterometallic Coordination Cubic Cages $\left[\mathrm{M}_{8}^{\mathrm{II}} \mathrm{Cu}_{6}{ }_{6}\right](\mathrm{M}=\mathrm{Ni}, \mathrm{Co})$. Cryst. Growth Des. 2018, 18, 4555-4561. [CrossRef]

18. Guo, J.; Xu, Y.-W.; Li, K.; Xiao, L.-M.; Chen, S.; Wu, K.; Chen, X.-D.; Fan, Y.-Z.; Liu, J.-M.; Su, C.-Y. Regio- and Enantioselective Photodimerization within the Confined Space of a Homochiral Ruthenium/Palladium Heterometallic Coordination Cage. Angew. Chem. Int. Ed. 2017, 56, 3852-3856. [CrossRef]

19. Wang, X.; Peng, P.; Xuan, W.; Wang, Y.; Zhuang, Y.; Tian, Z.; Cao, X. Narcissistic chiral self-sorting of molecular face-rotating polyhedral. Org. Biomol. Chem. 2018, 16, 34-37. [CrossRef]

20. Schweiger, M.; Seidel, S.R.; Schmitz, M.; Stang, P.J. Rational Design of Chiral Nanoscale Adamantanoids. Org. Lett. 2000, 2, 1255-1257. [CrossRef]

21. Dong, J.; Zhou, Y.; Zhang, F.; Cui, Y. A Highly Fluorescent Metallosalen-Based Chiral Cage for Enantioselective Recognition and Sensing. Chem. Eur. J. 2014, 20, 6455-6461. [CrossRef]

22. Sun, B.; Nurttila, S.S.; Reek, J.N.H. Synthesis and Characterization of Self-Assembled Chiral Fe ${ }_{2}{ }_{2} \mathrm{~L}_{3} \mathrm{Cages}_{\text {. }}$ Chem. Eur. J. 2018, 24, 14693-14700. [CrossRef] 
23. Tan, C.; Jiao, J.; Li, Z.; Liu, Y.; Han, X.; Cui, Y. Design and Assembly of a Chiral Metallosalen-Based Octahedral Coordination Cage for Supramolecular Asymmetric Catalysis. Angew. Chem. Int. Ed. 2018, 57, 2085-2090. [CrossRef] [PubMed]

24. Zhang, P.; Wang, X.; Xuan, W.; Peng, P.; Li, Z.; Lu, R.; Wu, S.; Tian, Z.; Cao, X. Chiral separation and characterization of triazatruxene-based face-rotating polyhedral: The role of non-covalent facial interactions. Chem. Commun. 2018, 54, 4685-4688. [CrossRef] [PubMed]

25. Bhat, I.A.; Devaraj, A.; Howlader, P.; Chi, K.-W.; Mukherjee, P.S. Preparation of a chiral $\mathrm{Pt}_{12}$ tetrahedral cage and its use in catalytic Michael addition reaction. Chem. Commun. 2018, 54, 4814-4817. [CrossRef] [PubMed]

26. Murase, T.; Peschard, S.; Horiuchi, S.; Nishioka, Y.; Fujita, M. Remote chiral transfer into [2+2] and [2+ 4] cycloadditions within self-assembled molecular flasks. Supramol. Chem. 2011, 23, 199-208. [CrossRef]

27. Argent, S.P.; Riis-Johannessen, T.; Jeffery, J.C.; Harding, L.P.; Ward, M.D. Diastereoselective formation and optical activity of an $\mathrm{M}_{4} \mathrm{~L}_{6}$ cage complex. Chem. Commun. 2005, 4647-4649. [CrossRef] [PubMed]

28. Albrecht, M.; Burk, S.; Weis, P. Chiral Confined Space: Induction of Stereochemistry in a $\mathrm{M}_{4} \mathrm{~L}_{4}$ Metallosupramolecular Container. Synthesis 2008, 2963-2967. [CrossRef]

29. Ren, D.-H.; Qiu, D.; Pang, C.-Y.; Li, Z.; Gu, Z.-G. Chiral tetrahedral iron(II) cages: Diastereoselective subcomponent self-assembly, structure interconversion and spin-crossover properties. Chem. Commun. 2015, 51, 788-791. [CrossRef]

30. Ousaka, N.; Clegg, J.K.; Nitschke, J.R. Nonlinear Enhancement of Chiroptical Response through Subcomponent Substitution in $\mathrm{M}_{4} \mathrm{~L}_{6}$ Cages. Angew. Chem. Int. Ed. 2012, 51, 1464-1468. [CrossRef]

31. Yan, L.-L.; Tan, C.-H.; Zhang, G.-L.; Zhou, L.-P.; Bünzli, J.-C.; Sun, Q.-F. Stereocontrolled Self-Assembly and Self-Sorting of Luminescent Europium Tetrahedral Cages. J. Am. Chem. Soc. 2015, 137, 8550-8555. [CrossRef]

32. Wisser, B.; Chamayou, A.-C.; Miller, R.; Scherer, W.; Janiak, C. A chiral $\mathrm{C}_{3}$-symmetric hexanuclear triangular-prismatic copper(ii) cluster derived from a highly modular dipeptidic N,N'-terephthaloyl-bis(Saminocarboxylato) ligand. CrystEngComm 2008, 10, 461-464. [CrossRef]

33. Chen, Z.; Liu, X.; Wu, A.; Liang, Y.; Wang, X.; Liang, F. Synthesis, structure and properties of an octahedral dinuclear-based $\mathrm{Cu}_{12}$ nanocage of trimesoyltri(L-alanine). RSC Adv. 2016, 6, 9911-9915. [CrossRef]

34. Zhang, Z.-J.; Shi, W.; Niu, Z.; Li, H.-H.; Zhao, B.; Cheng, P.; Liao, D.-Z.; Yan, S.-P. A new type of polyhedron-based metal-organic frameworks with interpenetrating cationic and anionic nets demonstrating ion exchange, adsorption and luminescent properties. Chem. Commun. 2011, 47, 6425-6427. [CrossRef]

35. Boer, S.A.; Turner, D.R. Self-selecting homochiral quadruple-stranded helicates and control of supramolecular chirality. Chem. Commun. 2015, 51, 17375-17378. [CrossRef] [PubMed]

36. Chen, L.; Kang, J.; Cui, H.; Wang, Y.; Liu, L.; Zhang, L.; Su, C.-Y. Homochiral coordination cages assembled from dinuclear paddlewheel nodes and enantiopure ditopic ligands: Syntheses, structures and catalysis. Dalton Trans. 2015, 44, 12180-12188. [CrossRef] [PubMed]

37. Xie, Y.; Yang, H.; Wang, Z.U.; Liu, Y.; Zhou, H.-C.; Li, J.-R. Unusual preservation of polyhedral molecular building units in a metal-organic framework with evident desymmetrization in ligand design. Chem. Commun. 2014, 50, 563-565. [CrossRef]

38. Lu, W.; Yuan, D.; Yakovenko, A.; Zhou, H.-C. Surface functionalization of metal-organic polyhedron for homogeneous cyclopropanation catalysis. Chem. Commun. 2011, 47, 4968-4970. [CrossRef] [PubMed]

39. Li, J.-R.; Yu, J.; Lu, W.; Sun, L.-B.; Sculley, J.; Balbuena, P.B.; Zhou, H.-C. Porous materials with pre-designed single-molecule traps for $\mathrm{CO}_{2}$ selective adsorption. Nat. Commun. 2013, 4, 1538. [CrossRef]

40. Prakash, M.J.; Oh, M.; Liu, X.; Han, K.N.; Seong, G.H.; Lah, M.S. Edge-directed $\left[\left(\mathrm{M}_{2}\right)_{2} \mathrm{~L}_{4}\right]$ tetragonal metal-organic polyhedra decorated using a square paddle-wheel secondary building unit. Chem. Commun. 2010, 46, 2049-2051. [CrossRef]

41. Craig, G.A.; Larpent, P.; Kusaka, S.; Matsuda, R.; Kitagawa, S.; Furukawa, S. Switchable gate-opening effect in metal-organic polyhedra assemblies through solution processing. Chem. Sci. 2018, 9, 6463-6469. [CrossRef]

42. Brega, V.; Zeller, M.; He, Y.; Lu, H.P.; Klosterman, J.K. Multi-responsive metal-organic lantern cages in solution. Chem. Commun. 2015, 51, 5077-5080. [CrossRef]

43. Boer, S.A.; White, K.F.; Slater, B.; Emerson, A.J.; Knowles, G.P.; Donald, W.A.; Thornton, A.W.; Ladewig, B.P.; Bell, T.D.M.; Hill, M.R.; et al. A Multifunctional, Charge-Neutral, Chiral Octahedral $\mathrm{M}_{12} \mathrm{~L}_{12}$ Cage. Chem. Eur. J. 2019, 25, 8489-8493. [CrossRef] 
44. Mollick, S.; Mukherjee, S.; Kim, D.; Zhiwei, Q.; Desai, A.V.; Saha, R.; More, Y.D.; Jiang, J.; Lah, M.S.; Ghosh, S.K. Hydrophobic Shielding of Outer Surface: Enhancing the Chemical Stability of Metal-Organic Polyhedra. Angew. Chem. Int. Ed. 2019, 58, 1041-1045. [CrossRef] [PubMed]

45. Boer, S.A.; Turner, D.R. Metallosupramolecular Architectures of Ambivergent Bis(Amino Acid) Biphenyldiimides. Chem. Asian J. 2019, 14, 2853-2860. [CrossRef]

46. Boer, S.A.; Cox, R.P.; Beards, M.J.; Wang, H.; Donald, W.A.; Bell, T.D.M.; Turner, D.R. Elucidation of naphthalene diimide metallomacrocycles and catenanes by solvent dependent excimer and exciplex emission. Chem. Commun. 2019, 55, 663-666. [CrossRef] [PubMed]

47. Kyratzis, N.; Cao, W.; Izogordina, E.I.; Turner, D.R. Structural changes in coordination polymers in response to small changes in steric bulk (H vs. Me): An experimental and theoretical study. CrystEngComm 2018, 20, 4115-4126. [CrossRef]

48. Boer, S.A.; Turner, D.R. A robust metallomacrocyclic motif for the formation of interpenetrated coordination polymers. CrystEngComm 2017, 19, 2402-2412. [CrossRef]

49. Boer, S.A.; Turner, D.R. Interpenetration in $\pi$-rich mixed-ligand coordination polymers. Cryst. Growth Des. 2016, 16, 6294-6303. [CrossRef]

50. Boer, S.A.; Hawes, C.S.; Turner, D.R. Engineering entanglement: Controlling the formation of polycatenanes and polyrotaxanes using $\pi$ interactions. Chem. Commun. 2014, 50, 1125-1127. [CrossRef]

51. Rogan, Y.; Malpass-Evans, R.; Carta, M.; Lee, M.; Jansen, J.C.; Bernardo, P.; Clarizia, G.; Tocci, E.; Friess, K.; Lanc, M.; et al. A highly permeable polyimide with enhanced selectivity for membrane gas separations. J. Mater. Chem. A 2014, 2, 4874-4877. [CrossRef]

52. Faghihi, K.; Moghanian, H. ynthesis and Characterization of New Optically Active Poly(amide-imide)s Based on N,N'-(Pyromellitoyl)-bis-L-Amino Acids and 1,3,4-Oxadiazole Moieties. Des. Monomers Polym. 2010, 13, 207-220. [CrossRef]

53. Cowieson, N.P.; Aragao, D.; Clift, M.; Ericsson, D.J.; Gee, C.; Harrop, S.J.; Mudie, N.; Panjikar, S.; Price, J.R.; Riboldi-Tunnicliffe, A.; et al. MX1: A bending-magnet crystallography beamline serving both chemical and macromolecular crystallography communities at the Australian Synchrotron. J. Synchrotron Rad. 2015, 22, 187-190. [CrossRef] [PubMed]

54. McPhillips, T.M.; McPhillips, S.E.; Chiu, H.J.; Cohen, A.M.; Deacon, A.M.; Ellis, P.J.; Garman, E.; Gonzalez, A.; Sauter, K.; Phizackerley, R.P.; et al. Blu-Ice and the Distributed Control System: Software for data acquisition and instrument control at macromolecular crystallography beamlines. J. Synchrotron Rad. 2002, 9, 401-406. [CrossRef] [PubMed]

55. Kabsch, W. XDS. Acta Cryst. Sect. D 2010, 66, 125-132. [CrossRef] [PubMed]

56. Sheldrick, G.M. SHELXT-Integrated space-group and crystal-structure determination. Acta Crystallogr. Sect. A 2015, 71, 3-8. [CrossRef]

57. Sheldrick, G.M. Crystal structure refinement with SHELXL. Acta Cryst. Sect. C 2015, 71, 3-8. [CrossRef]

58. Dolomanov, O.V.; Bourhis, L.J.; Gildea, R.J.; Howard, J.A.K.; Puschmann, H. OLEX2: A complete structure solution, refinement and analysis program. J. Appl. Cryst. 2009, 42, 339-341. [CrossRef]

59. Barbour, L.J. X-Seed-A software tool for supramolecular crystallography. J. Supramol. Chem. 2001, 1, 189-191. [CrossRef]

60. Spek, A.L. PLATON SQUEEZE: A tool for the calculation of the disordered solvent contribution to the calculated structure factors. Acta Cryst. Sect. C 2015, 71, 9-18. [CrossRef]

61. Prasad, T.K.; Hong, D.H.; Suh, M.P. High Gas Sorption and Metal-Ion Exchange of Microporous Metal-Organic Frameworks with Incorporated Imide Groups. Chem. Eur. J. 2010, 16, 14043-14050. [CrossRef]

62. Leong, C.F.; Faust, T.B.; Turner, P.; Usov, P.M.; Kepert, C.J.; Babarao, R.; Thornton, A.W.; D'Alessandro, D.M. Enhancing selective $\mathrm{CO}_{2}$ adsorption via chemical reduction of a redox-active metal-organic framework. Dalton Trans. 2013, 42, 9831-9839. [CrossRef]

63. Li, G.-B.; Yang, Q.-Y.; Pan, R.-K.; Liu, S.-G. Diverse cobalt(ii) coordination polymers for water/ethanol separation and luminescence for water sensing applications. CrystEngComm 2018, 20, 3891-3897. [CrossRef]

64. Li, G.-B.; Liu, J.-M.; Cai, Y.-P.; Su, C.-Y. Structural Diversity of a Series of Mn(II), Cd(II), and Co(II) Complexes with Pyridine Donor Diimide Ligands. Cryst. Growth Des. 2011, 11, 2763-2772. [CrossRef]

65. Kang, G.; Jeon, Y.; Lee, K.Y.; Kim, J.; Kim, T.H. Reversible Luminescence Vapochromism and Crystal-to-Amorphous-to-Crystal Transformations of Pseudopolymorphic Cu(I) Coordination Polymers. Cryst. Growth Des. 2015, 15, 5183-5187. [CrossRef] 
66. Nakagaki, T.; Harano, A.; Fuchigami, Y.; Tanaka, E.; Kidoaki, S.; Okuda, T.; Iwanaga, T.; Goto, K.; Shinmyozu, T. Formation of Nanoporous Fibers by the Self-Assembly of a Pyromellitic Diimide-Based Macrocycle. Angew. Chem. Int. Ed. 2010, 49, 9676-9679. [CrossRef]

67. Nalluri, S.K.M.; Zhou, J.; Cheng, T.; Liu, Z.; Nguyen, M.T.; Chen, T.; Patel, H.A.; Krzyaniak, M.D.; Goddard, W.A.; Wasielewski, M.R.; et al. Discrete Dimers of Redox-Active and Fluorescent Perylene Diimide-Based Rigid Isosceles Triangles in the Solid State. J. Am. Chem. Soc. 2018, 141, 1290-1303. [CrossRef]

68. Colquhoun, H.M.; Zhu, Z.; Williams, D.J.; Drew, M.G.B.; Cardin, C.J.; Gan, Y.; Crawford, A.G.; Marder, T.B. Induced-Fit Binding of $\pi$-Electron-Donor Substrates to Macrocyclic Aromatic Ether Imide Sulfones: A Versatile Approach to Molecular Assembly. Chem. Eur. J. 2010, 16, 907-918. [CrossRef]

69. Liu, Z.-M.; Liu, Y.; Zheng, S.-R.; Yu, Z.-Q.; Pan, M.; Su, C.-Y. Assembly of Trigonal and Tetragonal Prismatic Cages from Octahedral Metal Ions and a Flexible Molecular Clip. Inorg. Chem. 2007, 46, 5814-5816. [CrossRef]

70. Zhang, Q.; Hamilton, D.G.; Feeder, N.; Teat, S.J.; Goodman, J.M.; Sanders, J.K.M. Synthesis and post-assembly modification of some functionalised, neutral $\pi$-associated [2]catenanes. New J. Chem. 1999, 23, 897-903. [CrossRef]

71. Iwanaga, T.; Nakamoto, R.; Yasutake, M.; Takemura, H.; Sako, K.; Shinmyozu, T. Cyclophanes within Cyclophanes: The Synthesis of a Pyromellitic Diimide-Based Macrocycle as a Structural Unit in a Molecular Tube and Its Inclusion Phenomena. Angew. Chem. Int. Ed. 2006, 45, 3643-3647. [CrossRef]

72. Ge, C.; Li, X.; Zhang, X.; Zhao, Y.; Zhang, R. 2,2'-(1,3,5,7-Tetra oxo-1,2,3,5,6,7-hexa-hydro-pyrrolo[3,4f]isoindole-2,6-di-yl)diacetic acid N,N-dimethyl formamide disolvate. Acta. Crystallogr. Sect. E 2009, 65, o2400. [CrossRef]

73. Barooah, N.; Sarma, R.J.; Baruah, J.B. Solid-state hydrogen bonded assembly of N,N'-bis(glycinyl)-pyromellitic diimide with aromatic guests. CrystEngComm 2006, 8, 608-615. [CrossRef]

74. Barooah, N.; Singh, W.M.; Baruah, J.B. Preferential deprotonation and conformational stability of dicarboxylic acids: A packing effect. J. Mol. Struc. 2008, 875, 329-338. [CrossRef]

75. Ge, C.-H.; Zhang, X.-D.; Zhang, H.-D.; Zhao, Y.; Li, X.-Q.; Zhang, R. Color Variety of Organic Salt of N,N'-Bis(Glycinyl)Pyromellitic Diimide and N-Containing Base. Mol. Cryst. Liq. Cryst. 2011, 534, 114-123. [CrossRef]

76. Barooah, N.; Baruah, J.B. Effect of phenyl group on the self assembly of N,N'-bis-(2-phenylglycinyl)pyromellitic diimide with aromatic hydrocarbons. J. Mol. Struc. 2008, 872, 205-211. [CrossRef]

77. Jana, P.; Maity, S.; Maity, S.K.; Ghorai, P.K.; Halder, D. Insights into H-aggregates and CH $\cdots$ O hydrogen bond mediated self-assembly of pyromellitic bisimide. CrystEngComm 2012, 14, 6586-6592. [CrossRef]

78. Barooah, N.; Sarma, R.J.; Batsanov, A.S.; Baruah, J.B. Structural aspects of adducts of N-phthaloylglycine and its derivatives. J. Mol. Struc. 2006, 791, 122-130. [CrossRef]

79. Joarder, B.; Mukherjee, S.; Chaudhari, A.K.; Desai, A.V.; Manna, B.; Ghosh, S.K. Guest-Responsive Function of a Dynamic Metal-Organic Framework with a $\pi$ Lewis Acidic Pore Surface. Chem. Eur. J. 2014, 20, 15303-15308. [CrossRef]

80. Thuéry, P.; Masci, B. Self-assembly of an Octa-uranate Cage Complex with a Rigid bis-Catechol Ligand. Supramol. Chem. 2003, 15, 95-99. [CrossRef]

81. Abrahams, B.F.; FitzGerald, N.J.; Robson, R. A Doughnut-Like $\left(\mathrm{Mn}^{\mathrm{III}}\right)_{12}$ Metallocycle Formed by a Rigid Angular Bis-Catecholate with a Nanometer-Sized Central Hole. Inorg. Chem. 2010, 49, 5953-5956. [CrossRef]

82. Kawakami, Y.; Ogishima, T.; Kawara, T.; Yamauchi, S.; Okamoto, K.; Nikaido, S.; Souma, D.; Jim, R.-H.; Kabe, Y. Silane catecholates: Versatile tools for self-assembled dynamic covalent bond chemistry. Chem. Commun. 2019, 55, 6066-6069. [CrossRef]

(C) 2020 by the authors. Licensee MDPI, Basel, Switzerland. This article is an open access article distributed under the terms and conditions of the Creative Commons Attribution (CC BY) license (http://creativecommons.org/licenses/by/4.0/). 